\title{
PENGEMBANGAN ALAT TANAM BENIH PADI LANGSUNG (ATABELA) METODE VAKUM
}

\section{(Development of Rice Seed Planting Tool (ATABELA) using The Vacuum Method )}

\author{
Muhammad Tahir Sapsal ${ }^{1 *}$, Muhammad Fadlian S $\mathbf{P}^{1)}$, dan Salengke ${ }^{1)}$ \\ ${ }^{1 *}$ Program Studi Keteknikan Pertanian, Fakultas Pertanian, Universitas Hasanuddin \\ *) email korespondensi: tahirsapsal@gmail.com
}

\begin{abstract}
Direct seed planting tools or commonly abbreviated as ATABELA have been commonly used in rice cultivation in Indonesia. One of the problems that often occur in the use of this tool is the inconsistency in the number of seeds released. Besides, the seeds that are issued are usually more than three seeds, so that it can cause competition in the growth process. Therefore, it is necessary to develop direct seed planting tools with precise seed dosage. This study aims to design an applicator for planting rice seeds directly by dropping the seeds using vacuum pressure. Another goal is to know the pressure that can be generated as well as the forward speed required to produce the desired vacuum pressure. The first step in this research is to identify the pressure needed to move the seeds, then design a tool based on the pressure data. The test is carried out using a DC motor as a substitute for wheel rotation to determine the forward speed required to obtain the required pressure. The moisture content of the seeds used is $22.71 \%$ and the required pressure is $97 \mathrm{kPa}$ ( $4 \mathrm{kPa}$ under standard atmospheric pressure), the required forward speed is $2.5 \mathrm{~m} / \mathrm{s}$, so it is necessary to modify the ratio of the wheel pulley to the drive shaft.
\end{abstract}

Keywords: Vacuum Seeder, Atabela, Rice Seeds, Paddy field.

\begin{abstract}
ABSTRAK
Alat tanam benih langsung atau yang biasa disingkat ATABELA telah umum digunakan pada budidaya padi di Indonesia. Salah satu masalah yang sering terjadi pada penggunaan alat ini yaitu, tidak konsistennya jumlah benih yang dikeluarkan. Disamping itu benih yang dikeluarkan biasanya lebih dari tiga benih, sehingga dapat menimbulkan persaingan dalam proses pertumbuhannya. Oleh karena itu perlu dikembangkan alat tanam benih langsung yang dosis benihnya presisi. Penelitian ini bertujuan untuk merancang aplikator alat tanam benih padi langsung dengan penjatuhan benih memanfaatkan tekanan vakum. Tujaun lainnya yaitu mengetahui tekanan yang dapat dihasilkan serta kecepatan maju yang dibutuhkan untuk menghasilkan tekanan vakum yang. Langkah awal dari penelitian ini yaitu mengidentifikasi tekanan yang dibutuhkan untuk memindahkan benih, kemudian membuat rancangan alat berdasarkan data tekanan tersebut. Pengujian dilakukan menggunakan motor DC sebagai pengganti putaran roda untuk mengetahui kecepatan maju yang dibutuhkan untuk memperoleh tekanan yang dibutuhkan. Kadar air dari benih yang digunakan $22.71 \%$ dan tekanan yang dibutuhkan $97 \mathrm{kPa}$ ( $4 \mathrm{kPa}$ di bawah tekanan standar atmosfer) kecepatan maju yang dibutuhkan $2.5 \mathrm{~m} / \mathrm{s}$ sehingga perlu dilakukan modifikasi pada perbandingan pulley roda dan poros penggerak.
\end{abstract}

Kata Kunci: Vacuum Seeder, Atabela, Benih padi, Sawah. 


\section{PENDAHULUAN}

Penabur benih padi secara langsung telah umum diterapkan dalam budidaya tanaman padi di lahan sawah. Aplikator yang digunakan disebut "Atabela" (alat tanam benih langsung). Alat ini banyak digunakan karena lebih praktis tanpa melalui proses penyemaian bibit di lahan, sehingga lebih praktis dan mengurangi penggunaan tenaga kerja. Hal tersebut tentunya dapat mengurangi biaya produksi. Bentuk atabela yang banyak digunakan berupa drum seeder. Alat ini memiliki konstruksi yang sederhana sehingga dapat dibuat oleh petani ataupun bengkel alat dan mesin pertanian. Drum seeder memiliki kapasitas kerja yang lebih besar dibandingkan sistem sebar benih langsung menggunakan tangan, akan tetapi terdapat beberapa kekurangan pada alat ini, antara lain jumlah benih yang dijatuhkan dalam larikan tidak teratur (Ananto, 2001).

Jumlah benih jatuh yang tidak teratur dapat menyebabkan sulitnya tercapai benih yang presisi dalam satu titik, terutama untuk memperoleh 1 atau 2 benih per titik. Hal ini dapat menyebabkan terjadinya persaingan dalam proses pertumbuhan padi. Beberapa penelitian tentang pengaruh jumlah bibit per lubang/titk tanam mengindikasikan bahwa jumlah bibit berpengaruh terhadap anakan total dan anakan produktif, jumlah bibit yang lebih kecil (2 bibit/pot) meningkatkan jumlah anakan, malai yang terbentuk dan produktivitas (Hadiyanti, 2018. Untuk itu perlu penerapan penanaman presisi.

Penanaman presisi dapat dinyatakan sebagai penempatan benih secara akurat pada setiap baris penanaman (Singh et al, 2005). System vakum dapat dimanfaatkan untuk memperoleh penjatahan bibit yang akurat hingga 1 bibit per titik. System ini disebut sebagai vacuum seeder dan telah banyak digunakan pada proses persemaian pada tanaman yang dibudidayakan di green house maupun untuk penanaman benih pada perkebunan di negara maju. Kelebihan alat tanam yang memanfaatkan tekanan vakum presisi antara lain memiliki kualitas kerja yang baik dibandingkan dengan alat tanam mekanik, tingkat presisi yang lebih baik dengan tingkat kerusakan benih yang lebih rendah, kontrol dan penyesuaian yang lebih baik dalam pemeliharaan dan terhadap penyimpangan penjatahan benih, dan spektrum penerapan yang lebih luas (Soos et al, 1989).

Salah satu bentuk vacuum seeder yaitu menggunakan seeder yang berbentuk seperti jarum, dimana ukuran jarum dapat mempengaruhi ketepatan penjatahan. Zhang dan Song (2009) melakukan pengujian menggunakan vacuum seeder berbentuk jarum pada benih padi hibrida dan memperoleh hasil yang memenuhi persyaratan pembenihan dengan tingkat kerusakan benih yang rendah. Hasil penelitian mereka menunjukkan bahwa faktor terpenting yang mempengaruhi kinerja penjatahan adalah nilai vakum kemudian sudut dari ujung jarum dan kecepatan putaran roller. Vacuum seeder membutuhkan mekanisme untuk membangkitkan kondisi vakum, As'ad (2018) telah mengembangkan model mekanisme yang dapat digunakan untuk membangkitkan penurunan tekanan yang dibutuhkan untuk memindahkan benih padi. Penurunan tekanan diperoleh dari pompa hisap yang digerakkan menggunakan mekanisme 4 batang hubung. Mekanisme ini menghasilkan gerakan maju mundur sehingga menggerakkan pompa yang dapat menghasilkan penurunan tekanan yang dibutuhkan untuk mengambil benih padi. Pada penelitian tersebut, alat penghisap digerakkan secara langsung pada poros empat batang penghubung sehingga belum dapat digunakan di lahan.

Berdasarkan uraian di atas, maka perlu dilakukan pengembangan terhadap mekanisme pemindah benih yang telah dikembangkan sebelumnya menjadi alat tanam benih yang mampu menempatkan benih padi dengan jumlah benih yang akurat memanfaatkan kondisi vakum untuk memindahkan benih dari wadah (hopper) ke lahan.

\section{Tujuan Penelitian}

Penelitian ini bertujuan untuk merancang aplikator alat tanam benih padi langsung dengan penjatuhan benih memanfaatkan tekanan vakum. Penggerak mekanisme pemindah benih berasal dari putaran roda. Sehingga penelitian ini juga bertujuan untuk mengetahui kecepatan maju yang dibutuhkan untuk menghasilkan tekanan vakum yang dibutuhkan untuk memindahkan benih padi ke 
lahan serta profil perubahan tekanan yang terjadi.

\section{METODOLOGI PENELITIAN}

\section{Alat}

Alat-alat yang diperlukan dalam penelitian ini antara lain peralatan konstruksi, yang meliputi : mesin las, gurinda, mesin bor, kunci pas, meteran dan peralatan konstruksi lainya. Sementara peralatan pengujian meliputi : tachometer, meteran, stopwatch, kamera, motor DC 12 V $110 \mathrm{rpm}$, SSR, alat tulis, dan instumen perekam kecepatan putar dan tekanan yang terdiri dari sensor tekanan MPX5100GP, microcontroller ATMega 32 dan rotary encoder. Untuk mengetahui sifat fisik benih yang berkaitan dengan pemindahan dengan tekanan vakum menggunakan jangka sorong, timbangan, sistem vakum.

\section{Bahan}

Bahan pembuatan unit antara lain besi berongga, poros baja, roda, mur, baut, V-belt, puli, pompa hisap, besi plat dan bearing.

Bahan pengujian dalam penelitian ini yaitu benih padi yang telah diperam.

\section{Prosedur Penelitian}

Penelitian ini meliputi pengukuran sifat fisk benih untuk mengetahui karakteristik benih yang digunakan serta untuk mengukur penurunan tekanan yang dibutuhkan untuk memindahkan benih. Selanjutnya dilakukan perancangan mekanisme penggerak pompa yang digunakan untuk menciptakan kondisi vakum. Setelah itu dilakukan perancangan aplikator kemudian melakukan pengujian.

\section{Pengukuran sifat fisik benih}

Parameter yang diukur terdiri dari (1) massa benih; (2) panjang dan diameter benih; (3) kadar air; dan (4) penurunan tekanan yang dibutuhkan untuk menarik benih.

Massa benih diperoleh dengan menimbang benih yang telah diperam selama 24 jam sebanyak 50 sampel menggunakan timbangan. Pengukuran dimensi benih yaitu panjang dan diameter benih menggunakan jangka sorong. Pengukuran kadar air benih menggunakan metode gravimetri, yaitu menimbang massa benih yang telah diperam sebanyak 50 sampel sebelum dimasukkan ke dalam oven. Bahan disimpan di dalam oven selama 24 jam pada suhu $110{ }^{\circ} \mathrm{C}$. kadar air dihitung menggunakan persamaan :

$$
K_{a}=\frac{\left(M_{a w a l}-M_{a k h i r}\right)}{M_{a k h i r}} \times 100 \%
$$

Keterangan:

$\mathrm{K}_{\mathrm{a}}=$ kadar air (\%bk)

$\mathrm{M}_{\text {awal }}=$ massa awal $(\mathrm{g})$

$\mathrm{M}_{\mathrm{akhir}}=$ massa akhir $(\mathrm{g})$

Besarnya tekanan vakum yang dibutuhkan untuk menarik benih diperoleh dengan melakukan pengujian pada sistem vakum dengan penurunan tekanan $5,10,15$, $20,25,30,35,40,50,55$, dan $60 \mathrm{kPa}$. Benih diletakkan pada wadah kemudian didekatkan pada lubang hisap dengan jarak sekitar $1-5$ $\mathrm{mm}$.

\section{Perancangan mekanisme penggerak pompa hisap/vakum}

Mekanisme penggerak dirancang agar dapat menggerakkan pompa secara translasi memanfaatkan putaran dari roda penggerak, sehingga mekanisme ini didekati dengan mekanisme empat batang hubung dengan bentuk sebagai berikut :

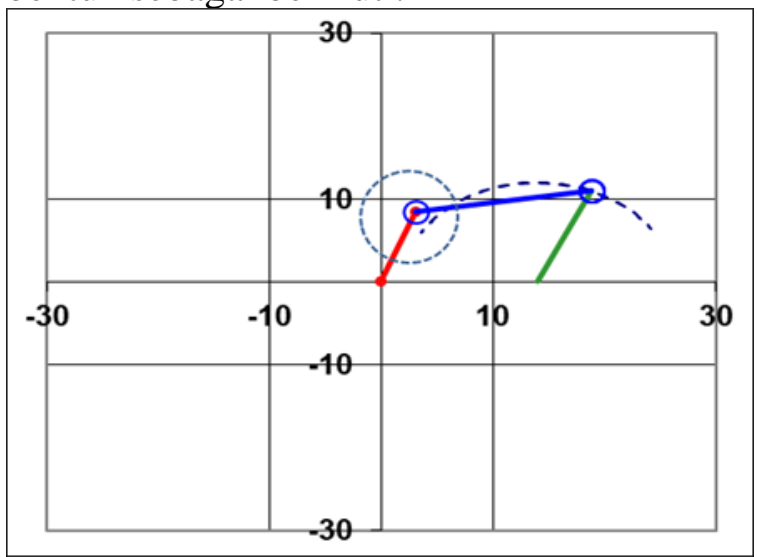

Gambar 1. Mekanisme penggerak pompa Keterangan :

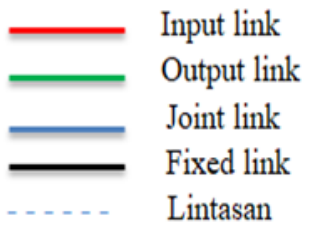

Input link terhubung dengan roda melalu puli dan sabuk, putaran dari input link menghasilkan Gerakan maju-mundur pada pertemuan joint link dan output link, tuas pompa dipasang pda titik tersebut untuk menghasilkan gerakan menghisap. 


\section{Rancangan Aplikator}

Aplikator terdiri dari penggerak pompa dan pompa hisap yang berfungsi sebagai mekanisme pengisap, roda, hopper dan rangka.

Mekanisme penggerak pompa dipasang pada aplikator dengan sumber penggeraknya berasal dari putaran roda saat aplikator bergerak maju. Ilustrasi posisi mekanisme penggerak pompa hisap yang terpsang pada aplikator dapat dilihat pada gambar berikut :

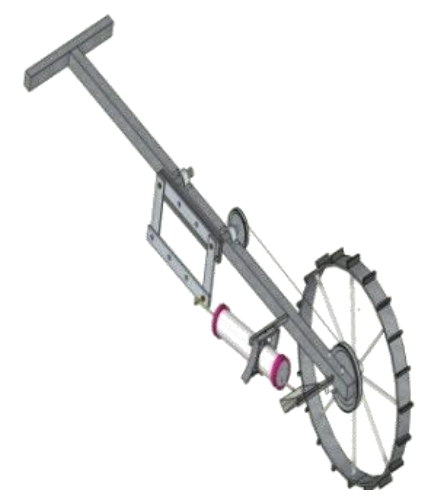

Gambar 2. Ilustrasi penempatan mekanisme penggerak pompa hisap

Putaran dari roda berfungsi sebagai penggerak mekanisme pengisap benih. Mekanisme pengisap berfungsi sebagai penghasil tekanan yang dibutuhkan untuk mengambil benih padi dari wadah.

\section{Pengujian}

Bagian yang diuji pada penelitian ini yaitu mekanisme penggerak pemindah benih. Pengujian dilakukan dengan menggerakkan mekanisme tersebut menggunakan motor DC $12 \mathrm{~V}$ yang diasumsikan sebagai gerakan dari roda aplikator. Adapun langkah-langkahnya sebagai berikut :

1. Merendam benih padi yang akan diuji selama 24 jam kemudian diperam selama 24 jam.

2. Memilih benih yang telah mengeluarkan kecambah.

3. Mengambil sampel benih sebanyak 500 gram dan diletakkan pada wadah benih.

4. Memutar roda penggerak pada $1 \mathrm{rps}$.

5. Mencatat jumlah benih yang terisap.

6. Mencatat penurunan tekanan menggunakan sensor MPX5100GP

7. Mengulangi langkah di atas pada putaran roda 1,5 dan 2 rps.

\section{HASIL DAN PEMBAHASAN}

\section{Mekanisme penggerak pompa}

Mekanisme penggerak pompa terdiri dari tabung pengisap dengan panjang tabung 22,3 $\mathrm{cm}$ dan diameter tabung $3 \mathrm{~cm}$, selang pengisap dengan diameter $3 \mathrm{~mm}$, wadah benih dengan panjang $27 \mathrm{~cm}$ serta lebar $9 \mathrm{~cm}$, lahar, needle roller bearing dengan diameter dalam $16 \mathrm{~mm}$, diameter luar $22 \mathrm{~mm}$, dan tebal $16 \mathrm{~mm}$ mekanisme empat batang penghubung dengan panjang lengan depan $12 \mathrm{~cm}$, lengan belakang $9 \mathrm{~cm}$, lengan atas $16 \mathrm{~cm}$, dan lengan bawah 14 $\mathrm{cm}$.

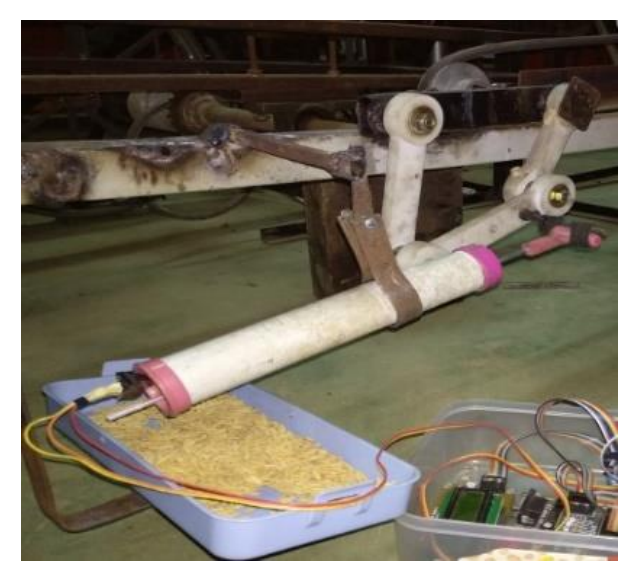

Gambar 3. Mekanisme penggerak pompa

Pada mekanisme ini, terpasang sensor tekanan MPX5100GP untuk membantu proses perekaman data tekanan saat pengujian, sensor ini dipasang pada bagian ujung pompa di samping selang pengisap yang terhubung dengan modul mikrokontroler ATmega 32. Data tekanan yang terbaca dan telah diolah oleh modul mikrokontroler dikirim ke komputer melalui koneksi data serial dengan protokol RS 232. Sehingga data tekanan dapat terbaca secara real-time selama pengujian.

Penggerak pompa ditempatkan pada rangka aplikator dan terhubung dengan roda dari aplikator, yang berfungsi sebagai sumber tenaga putar dari mekanisme penggerak pompa. Rangka pada penelitian ini hanya menggunakan satu roda bersirip dengan diameter $45 \mathrm{~cm}$ dan panjang rangka $170 \mathrm{~cm}$ dan dilengkapi dengan pegangan pengarah alat berukuran $30 \mathrm{~cm}$. 


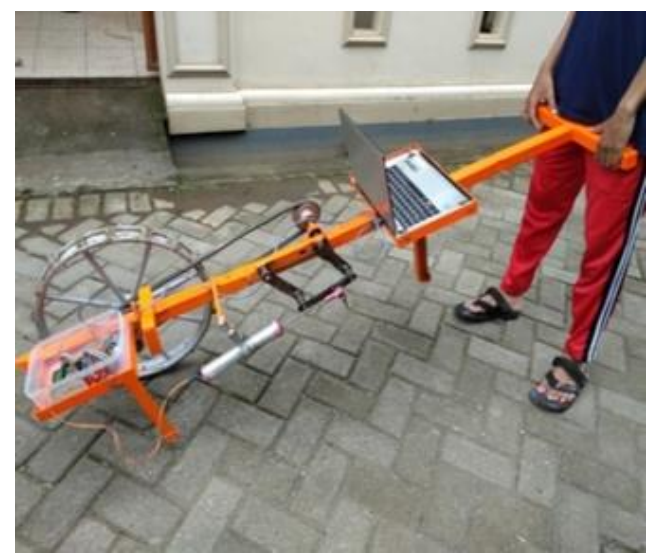

Gambar 4. Aplikator hasil rancangan

Pengujian dilakukan untuk mengetahui kecepatan putar yang dibutuhkan untuk menghasilkan tekanan vakum yang dapat memindahkan benih. Untuk itu, pada proses pengujian roda digantikan dengan motor DC $12 \mathrm{~V}$ yang kecepatan putarnya dikontrol menggunakan mikrokontroler dan SSR yang berfungsi sebagai driver motor. Hal ini dilakukan untuk memperoleh kecepatan yang konsisten, sehingga memudahkan untuk menentukan kecepatan maju minimum alat.

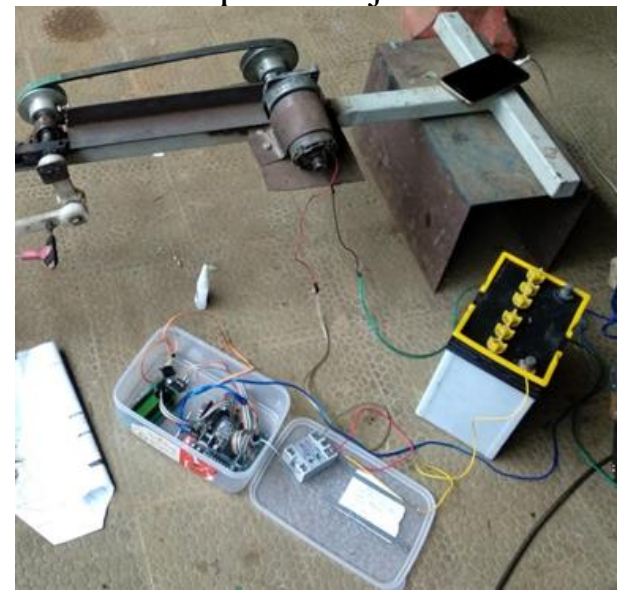

Gambar 5. Pemasangan motor DC untuk pengujian

Motor DC menggunakan aki 12 volt, puli pada motor berdiameter $7,5 \mathrm{~cm}$ dan pada poros penggerak pompa berdiameter $3 \mathrm{~cm}$. Puli ini memiliki satu lintasan sehingga digunakan Vbelt tipe A dengan panjang $26 \mathrm{~cm}$, tipe ini biasa dipakai sebagai transmisi tenaga selain itu ekonomis dan mudah diganti.

\section{Sifat fisik benih}

Benih yang telah diperam dan berkecambah mengandung kadar air $22.71 \%$, rata-rata massa benih padi adalah 0,025 gram, panjang rata-rata $4.9 \mathrm{~mm}$, lebar $3.35 \mathrm{~mm}$ dan tebal 2.61 $\mathrm{mm}$. Pada pengujian pengisapan dengan jarak antara benih dan selang pengisap kurang dari 5 $\mathrm{mm}$, benih dapat terisap pada tekanan $97 \mathrm{kPa}$ atau sebesar $4 \mathrm{kPa}$ di bawah tekanan atmosfer standar, hal ini sama dengan hasil penelitian yang dilakukan oleh Zhang dan Song (2009).

\section{Profil Perubahan Tekanan Pompa Hisap}

Penggerak pompa disimulasikan dengan menggunakan motor DC sebagai sumber penggeraknya, pengujian dilakukan dengan menggunakan beberapa kecepatan putar, dan diperoleh hasil sebagai berikut :

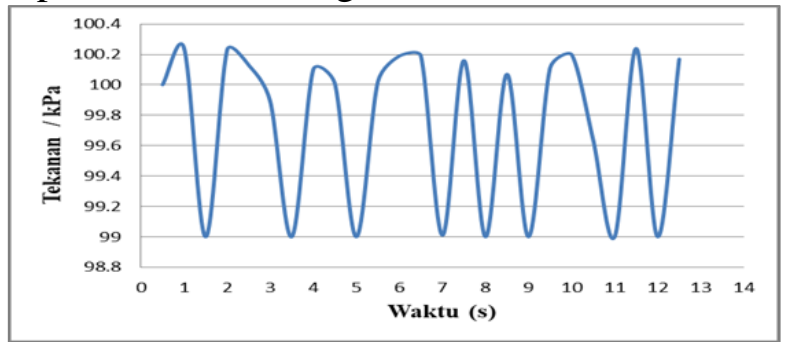

Gambar 6. Kecepatan putar $1 \mathrm{rps}$

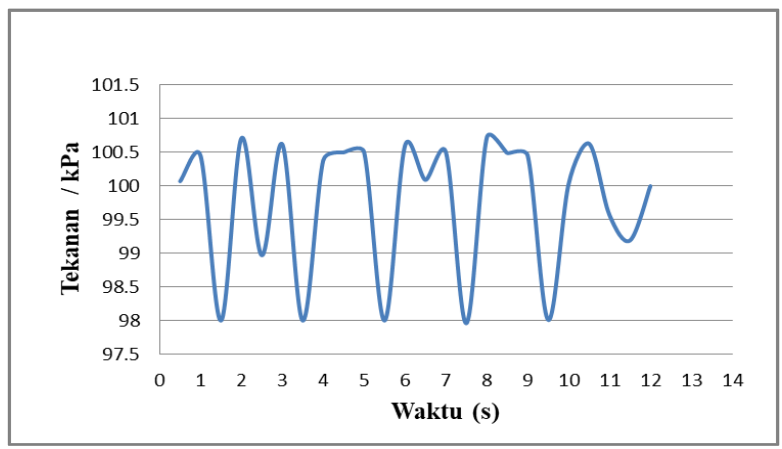

Gambar 7. Kecepatan putar 1.5 rps

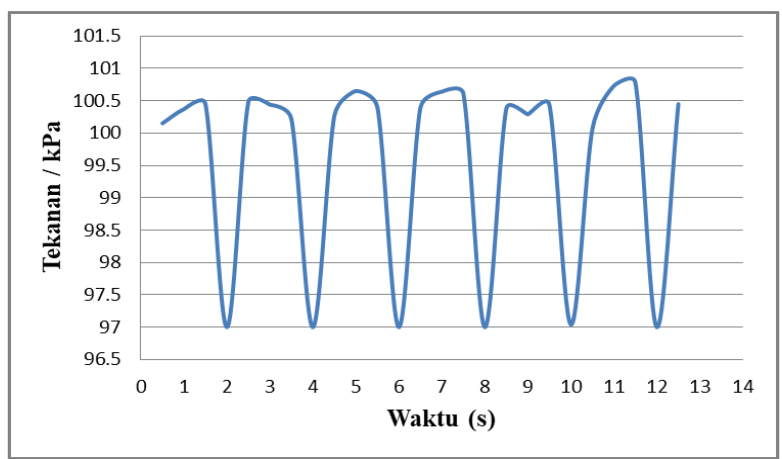

Gambar 8. Kecepatan putar 2 rps

Tekanan yang dihasilkan dipengaruhi oleh kecepatan putar motor penggerak, semakin tinggi kecepatan putar semakin tinggi pula penurunan tekanan yang dihasilkan. Pada kecepatan putar 1 rps penurunan tekanan hanya sebesar $2 \mathrm{kPa}$, sementara pada 
kecepatan putar $1.5 \mathrm{rps}$ sebesar $3 \mathrm{kPa}$, dan 2 rps sebesar $4 \mathrm{kPa}$.

Tekanan yang dibutuhkan untuk memindahkan benih yang telah diperam sebesar $97 \mathrm{kPa}$, Sehingga kecepatan putar motor yang dibutuhkan untuk memindahkan benih padi dari wadah ke lahan harus lebih dari 2 rps. Di mana mekanisme hasil rancangan dapat memperoleh nilai tersebut. Tekanan hisap memperngaruhi secara signifikan persentasi jumlah benih yang diambil bahkan persentasi keberhasilan dalam mengambil benih tepat 1 butir sedangkan diameter selang penghisap mempengaruhi (Gaikwad dan Sirohi, 2008).

Kecepatan rata-rata seseorang yang berjalan santai berkisar $0,5 \mathrm{~m} / \mathrm{s}-1,1 \mathrm{~m} / \mathrm{s}$ pada usia dewasa. Puli yang digunakan pada motor DC berdiameter $7.5 \mathrm{~cm}$ dan pada poros penggerak pompa sebesar $3 \mathrm{~cm}$, jika diameter roda $45 \mathrm{~cm}$ dan diasumsikan tenggelam dilumpur sedalam $5 \mathrm{~cm}$ maka dibutuhkan kecepatan maju $2.5 \mathrm{~m} / \mathrm{s}$ untuk memperoleh tekanan yang dibutuhkan. Sehingga tidak efektif jika menggunakan tenaga manusia. untuk itu perlu dilakukan modifikasi untuk meningkatkan penurunan tekanan yang dihasilkan dengan kecepatan maju yang lebih rendah, hal ini dapat dilakukan dengan memperbesar rasio antara puli roda dengan puli poros penggerak pompa yang saat ini sebesar 1:2.5 menjadi 1: 7 sehingga diperoleh kecepatan maju $0.9 \mathrm{~m} / \mathrm{s}$ yang sesuai dengan kemampuan manusia dewasa.

\section{KESIMPULAN}

Berdasarkan hasil yang diperoleh dari peneilitian ini dapat disimpulkan sebagai berikut:

1. Telah dirancang aplikator alat tanam benih padi langsung dengan mekanisme pemindah benih menggunakan takanan vakum.

2. Tekanan yang dibutuhkan untuk memindahkan benih padi yang telah diperam dan berkecambah sebesar $97 \mathrm{kPa}$

3. Mekanisme penggerak pompa pemindah benih mampu menghasilkan tekanan yang dibutuhkan.
4. Kecapatan maju yang dibutuhkan oleh aplikator untuk mencapai tekanan hisap sebesar $2.5 \mathrm{~m} / \mathrm{s}$

\section{DAFTAR PUSTAKA}

Ananto, E. (2001). Alat Tanam Padi Tebar Langsung Tipe Drum . Proyek Penelitian Pengembangan Pertanian Rawa TerpaduISDP. Badan Penelitian dan Pengembangan Pertanian.

As'ad, A, Sapsal, MT, Salengke S. (2018). Desain dan Pengujian Mekanisme Pemindah Benih Padi dengan Metode Hisap. Jurnal Agritechno, 11(1), 1 - 10.

Gaikwad, BB, Sirohi, NPS. (2008). Design of a Low-cost Pneumatic Seeder for Nursery Plug Trays. Biosystems Engineering 99 (3) 322- 329.

Hadiyanti, N. (2018). Uji Pengaruh Jumlah bibit per Lubang Tanam Terhadap Pertumbuhan dan Hasil Padi (Oryza sativa L.) di Green House. Jurnal Agrinika, 2(2), 127-134.

Singh, RC, Singh, G, Saraswat, DC. (2005) Optimization of Design an Operational Parameters of a Pneumatic Seed Metering Device for Planting Cottonseeds. Biosystems Engineering, 92 (4), 429 438.

Soos, P, Szule, ZS, Fuzy, J . (1989). A Comparative Evaluation of Modern Sugar Beet Drills. Bulletin of the University of Agricultural Science, Gödöllo. 1, 166170.

Zhang, X, Song, J. (2009). Design and Research on Rice Precision Needle-like Vacuum Seeder. Nongye jixie xuebao, 40(3), 69-71. 